\title{
The Rising Trend in the Use of Credit Cards in Bangladesh and Its Implications on Over-indebtedness and Its Difficulties in Personal Finance
}

\author{
Tajul Islam ${ }^{1, *}$, Mohd. Redwanul Karim ${ }^{2}$, Nurul Alam ${ }^{3}$ \\ ${ }^{1}$ Department of Business Administration, North East University, Bangladesh \\ ${ }^{2}$ Sylhet Women's Medical College \& Hospital, Bangladesh \\ ${ }^{3}$ Business School, The University of Sydney, Australia
}

Copyright (C) 2015 by authors, all rights reserved. Authors agree that this article remains permanently open access under the terms of the Creative Commons Attribution License 4.0 International License

\begin{abstract}
Research in the area of rising trend of credit card and heading towards debt has become a controversial issue since 2008 when the debt crisis began in European countries, especially with the collapsing of Iceland banking system. Since the Greek crisis arose, the relationship between credit card and consumer debt is being scrutinized among researchers and financial parties. As Credit card enables an individual to purchase certain products and services without having money in the account or paying immediately, it actually accelerate consumers to spend more and fall in deep debts. However, within credit limit set by the issuing company, and provide convenience and safety to the buying process it can also be considered as a good substitute for cash and cheque. Once a credit transaction is made, the customer is allowed either to make a full payment or to make a minimum payment within a specified period. The purpose of this study is to investigate the rising trend in the use of credit cards in Bangladesh and its implication on over-indebtedness and its difficulties in personal finance. To carry out this study a survey was conducted and 85 copies of a structured questionnaire were distributed among the credit card users of different banks in Bangladesh. This study found that majority of the participants $(60 \%)$ face financial difficulties with credit card debt and to keep up repayments up-to-date and the accumulating debt is seriously affecting the budgeting and personal finance leading to erratic consumption and decreased saving and or no saving at all and thereby they were bound to modify their saving. On the other hand, the quality of services provided by the credit card issuers ranked by the users of credit cards as excellent by $2.4 \%$, as good by $33 \%$, average by $25 \%$, poor by $15 \%$ and very poor by $25 \%$. Various statistical tools and test, such as Analysis of variance (ANOVA), Z-test were conducted to test hypotheses and to analyze collected data. Various tables and graphs were also used for descriptive analysis.
\end{abstract}

Keywords Credit Card, ATM, Consumer, Debit Card, Goods and Services
JEL Classification Code: G21, E51, L81, M15 and N7

\section{Introduction}

In this modern competitive marketing world, businesses and entrepreneurs continually monitor their business activities and develop newer initiatives and ventures to fit into different strategies with a view to ensuring and attaining higher profitability. Credit card companies and banks especially are more and more allured to launch credit cards with high interest rates out of the lust for making ever-greater profits. Michelle Norris [1] explained that beyond the markets, beyond the mortgage crisis, here's another sign of the strained economy: people are having a harder time paying those credit card bills, delinquencies are creeping upward, and banks are jacking up interest rates, lowering credit limits and introducing new fees.

In Bangladesh, there was a dramatic change over the last 10 years-only few banks were offering credit card facilities around the year 2000, and now almost all the banks operating here are offering credit cards with an average interest rate of $30 \%$, which is considered to be very high in respect of the interest rate charged by banks and credit card companies in other countries. According to Bangladesh Bureau of Statistics 2008, Cited in Farukh, 2009 the advances made by the credit card companies was a staggering Tk. 489.51 corers, which would be surprisingly higher now-a-days.

Personal finance is defined as the way in which an individual or a family makes decisions in relation to their financial portfolio, budgeting, saving and spending monetary resources over time, taking into account various financial risks and future life events. It is the application of principles of finance to the planning of personal finance by individuals or families through construction of an appropriate plan meeting the personal and financial objectives and achieving 
a balanced management of financial resources of in possession, future earnings, investment growth and inflation. In ordinary terms, it is the process of efficiently controlling one's money and making informed decisions to keep one's finances in check and oneself out of debt.

Each and every society has changed from the time when a person was known for his personal character, and puritanical thrift was the norm and rule to guide all in a community. In the past, most people behaved in a way that would satisfy the 'self' rather than to create an image or build their 'persona' from non-essential purchases and possessions to establish their identity and positions in the society. In contrast, people now-a-days are known for their lifestyle and the image built through their possessions. Manning, 2000 explained that revolving credit has been slipped into the toolbox of the average citizen through the careful marketing of the credit providers as an aid, an essential one, for the non-wealthy to participate in the culture-wide activity of individual identity creation and the maintenance of success. However, in eastern societies, especially in our country, "a penny saved is a penny earned" ethos is still working, and we are accustomed to do things which we can afford and we have been observing the individual responsibility model in personal financing. For example, it is still the practice of buying a land or house for cash in our country, in contrast to purchase a house in the western societies without getting a mortgage is something beyond reality. Financial credit, in our country, was a matter only related to business or commerce, however, over the last few years, the financial institutions have started to spread these services very aggressively to reach customers at an individual level of personal finance.

\section{Literature Review}

Banks including Bangladesh Bank: Banks offering credit cards, and 'the Bangladesh Bank' the regulating body of the banks and other financial institutions in our country.

The usage of credit card has increased dramatically over the past few years and the growth of the use of credit card has been exponential rather than linear in our country and worldwide (Furnham \& Argyle, 1998). This has raised concerns that it could cause widespread financial difficulties and default among households who might struggle to keep up with their repayments (May, Tudela, \& Young, 2005). This great service of credit card loan facility undoubtedly has gained popularity among the middle class, higher middle class and of course to the upper class citizen of the nation. People now feel safer and comfortable in carrying a single piece of plastic card rather than carrying a bundle of money with them (Huq, 2011).

According to the Bangladesh Bank Statistics, the current usage has risen exponentially and the advances made by the Islamic Banks, Private Banks, Foreign Banks and State-owned Banks altogether at the end of December 2011 has totaled a staggering Tk. 1,769.59 corers, and number of credit card-holders has risen to 5.51 lac (Bangladesh Bank, 2011). The study by Farukh, 2009 revealed that in December 2008 the number of credit card holders was 4.02 lac and the advances made by then credit card offering Banks were Tk. 489.51 corers. It is a very stern revelation though that the average number of credit card users has risen by about $46 \%$ every year from 2008 to the end of December 2011, however, the annual growth rate for advances rose for the same period by a seemingly unbelievable $120 \%$, in comparison to the annual average growth rate between 2004 to 2008 was for local Banks $64.2 \%$ and Foreign Banks $20.4 \%$ giving an overall rate of $36.1 \%$ Farukh [9].

This is one of the most important stories swirling around the credit card industry worldwide right now that concerns debt (Andrew, 2014) (Bacchetta \& Gerlach, 1997). The worldwide data suggest that almost all individuals in the U.S. are habituated to making the indiscreet use of credit card that results in overwhelming debt. According to the latest statistics of the U.S. Census Bureau, 2010, U.S. citizens have over $\$ 886$ billion in credit card debt and the figure is expected to rise to $\$ 1.177$ trillion. Furthermore, according to a recent research in 2011, Americans are accrued by over $\$ 48$ billion in new credit card debt, $424 \%$ more than what they incurred in 2010 and $577 \%$ more than what they incurred in 2009 (Matthews, 2012). In the UK, approximately 24.5 million transactions worth $\$ 2.85$ billion are spent on credit cards per day (www.creditaction.org.uk).

Jaing [12] has found that credit card use varied considerably with age of the consumers. It is very often considered that people at their young age are more impulsive and inexperienced and indulge more in adventurous activities than they are grown up. Resultantly they end up in overwhelming debt.

The current research base dictates that less affluent customers and customers having less number of cards are more prone to use credit cards more than those having high income level and multiples cards Williamson [13] and they run into financial difficulties and debt. This was replicated by another study by Farinha, 2014 that the debt burden ratio increases for lower income households but decreases from a higher level of income onwards.

The extreme liberalization of the financial industry is linked to the increased availability of debt products and it helps to provide the money that fuels immediate consumption, a shift from deferred gratification, where one might have saved before purchasing a good Lury [15]. It's possible to see the strength of this argument in practice when it is seen that credit card companies make the facilities easily and highly available working with the philosophy of pay-flex 'buy now, pay later'. It is claimed that financial services industry is not simply meeting the demand for debt, but it is part of a process which is encouraging debt. This excessive liberalization of financial services and aggressive encouragement of uptake of credit facilities by the banks and other financial institutions may be attributed to a positive link between consumption behavior and credit growth 
(Bacchetta \& Gerlach, 1997).

They (Bangladesh Bank, 2011) found that credit growth has a significant positive impact on consumption growth, and credit availability affects saving behavior. They also show that household debt ratio is negatively correlated with the saving rate, with the saving rate declining and the household debt ratio rising between 1975 and 2005. This is consistent with other studies that find a positive link between consumption behavior and credit growth (Maki, 2000).

The causative factor for the customer over-indebtedness due to credit card debt was primarily thought to be due to rapid interest accumulation throughout the duration of repayment of the balance (Golmant \& Ulrich, 2007). Furthermore, the other important element of increased over-indebtedness is the stickiness of credit card interest rates (Calem \& Mester, 1995), which changes a little, though interest rates for other bank products rise or fall, and thereby the credit card operation earns a very high return in the banking industry at large, which is not at all a good news for the card users. It is claimed that more than three out of every four American families now-a-days are in debt, according to the Federal Reserve's Survey of Consumer Finances (Soong, 2008).

\section{Objectives of the Study}

Main objective of the study is to investigate the rising trend in the use of credit cards in Bangladesh and its implications on over-indebtedness and its difficulties in personal finance. Some supporting objectives are:

i) To examine the interaction of different variables, e.g. age, income level, multiple card holding, etc, giving rise to the increasing trend of credit card use and compare this within and between groups;

ii) To explore the respondents' views about the user friendliness, cost-effectiveness, satisfaction and security of the credit cards as well as to find out their views of the benefit of and the greater availability of credit facilities;

iii) To identify the implications of increased use of credit card on potential financial difficulties and debt;

iv) To identify issues and to describe the context of how the rising trend in use of credit card is creating difficulties in repayment, rendering the credit card users into debt and jeopardizing their budgeting of personal finance, and, thereby, influencing the consumption and saving behaviors of the survey participants;

v) To explore the respondents' views and ranking of the of service of providers of credit facilities;

vi) To inform the providers of credit cards as well as the consumers as to the relationship of high level of usage of credit cards and the efficient budgeting of personal finance, which may be a guiding principle for the providers to offer high tech information to their customers and for the users of credit cards not get into over-indebtedness and, thereby, safeguarding against potential financial difficulties in their lives by efficiently managing credit borrowing;

vii) Finally, to find out if any guidelines and legislation exist concerning the credit card industry as a whole and to examine the compliance of those, if any, with a view to ensuring responsible lending and borrowing.

\section{Methodology of the Study}

\subsection{Survey Method}

It was deemed in the meeting that we would need to obtain consent before interviewing the participants. The participating banks were connected following the approval and the issue of consent was discussed. The banks agreed to provide with the names and telephone numbers of their customers using credit cards, having obtained their informed consent in advance and willingness to participate in the survey.

This study of "the rising trend in the use of credit cards in Bangladesh and its implications on over-indebtedness and difficulties in personal finance" is a descriptive study designed to be a cross-sectional survey conducted in the form of a questionnaire. The survey was conducted through interviewing participants physically, over the telephone and electronically, depending on the availability and convenience of the participants.

As part of the survey, we enquired about the age of the credit card holders, their income levels, number of credit cards they held with credit limits and outstanding balances, with interest rates charged by the issuers, the repayment methods used by them. We also enquired if they found the credit cards 'user-friendly', 'cost-effective and satisfactory' and 'secured'. We further enquired if they found any difficulties in paying off the balance and if they ended up with any debt, which affected their budget and personal finance in any way. We finally requested them to rank the quality of service of the credit card issuers in the case when they faced difficulties in their personal finance.

\subsection{Questionnaire}

The questionnaire was designed to elicit information required to identify the existing practice of credit card use and to explore the difficulties, if any, in repayment of the loan and resulting drowning in debt. At the outset, we searched for any standardized, valid and relevant questionnaire that might have been used in the past to gain a picture of the level of use credit cards and the resultant over-indebtedness and difficulties in repaying the credit card loan. As none was available-we developed and piloted a questionnaire specifically for this survey. We tried to keep the questions short and simple and crafted it in such a way 
that the questions were readable, understandable, unambiguous and insightful. We included answers with dichotomous options, multiple choices and rating scales with clear instructions for ease of response. We initially included a total of fifteen questions in our draft questionnaire. We then piloted the questionnaire among people selected from a blend of focus group and experts-teachers, bankers, credit card users, civil servants, businessmen with a view to assessing the readability of the questionnaire, highlighting any ambiguous questions, identifying relevant issues that were not included in the questionnaire and estimating completion time.

\subsection{Participants}

Participants were assigned by all the credit card-issuing banks we contacted and were selected following simple random sampling method, from their list of credit card users obtaining their consent initially if they would be willing to participate in such a survey. Those who gave their prior consents were included and contacted for the survey interview. The participants were selected randomly from the central database of banks, so that the recruitment reflects country wide participation from a wide variety of backgrounds and demographic variables as well as from the whole of Bangladesh. The interviews were contacted face to face as well as through email or over the telephone for those who were found to be outside of the locality where the survey was carried out.

\subsection{Statistics}

This is a descriptive study designed to be questionnaire-based cross-sectional survey of credit card users. The questionnaires were both self-administered and interviewer-administered and the interviews were conducted by the researchers. Data were entered manually from the returned questionnaires into SPSS and all analysis performed using this program. For continuous variables from normally distributed sample and once the conditions of ANOVA is checked and satisfied, the one-way analysis of variance (ANOVA) is used to compare between group effect. The checks included examining descriptive statistics such as mean, standard deviation, standard error, range and confidence intervals, and test for homogeneity of variance. The main ANOVA result shows the combined between group effect represented by the F-statistic and significance level.

\section{Hypotheses of the Study}

Hypothesis 1: There is a significant effect of respondents' age on the duration of repaying the balance.

Hypothesis 2: There is a significant effect of respondents' findings the card use uncompleted on difficulties in repayment and running into debt.

Hypothesis 3: The duration of repayment of credit card balance neither cost effective nor satisfactory.

Hypothesis 4: There is a significant difficulty in paying off the balance of debt (Z-test).

Hypothesis 5: There is a significant effect of difficulties in repayment and debt level on budgeting and personal finance of credit card users.

\section{Data Analysis \& Results}

Interviews were conducted with 85 customers, though few of them actually were interviewed after several contacts. The interviews were conducted face-to-face, over telephone and also through email contact. Different modalities were used to improve response rate, and also to interview participants who were found to be out of the locality.

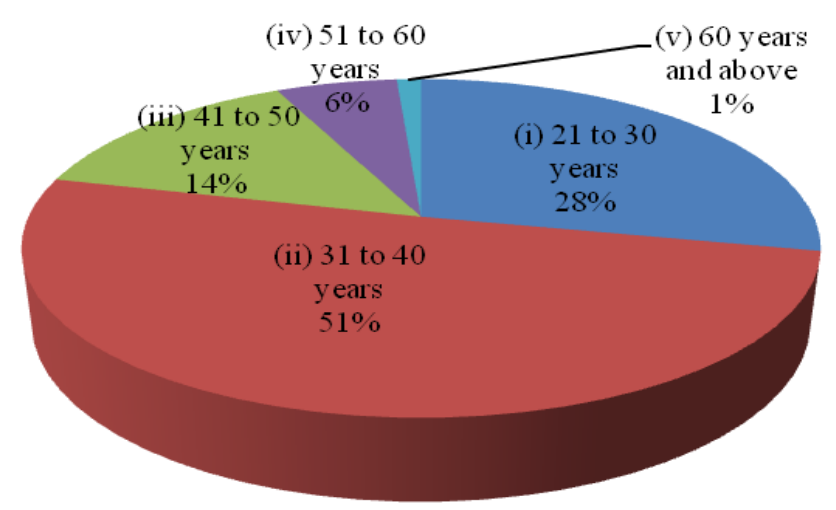

Figure 1. Age of credit card users

The Figure 1 show the age of credit card users - $28 \%$ of the customers are in the age group between 21 and 30 years, $51 \%$ of them between 31 and 40 years, $14 \%$ of them between 41 and 50 years and only $6 \%$ between 51 and 60 years. It reveals that the credit cards are mostly used by the age-groups 21 years and 40 years comprising $79 \%$, however, the use of cards was found to decline with increasing age, which is consistent with the findings of Jiang (2006) who stated "the fact that credit card borrowing has been found to vary considerably with the age of the consumer." 
Table 1. Number of credit cards held by respondents

\begin{tabular}{|c|c|c|c|c|c|}
\hline \multicolumn{2}{|c|}{} & Frequency & Percent & Valid Percent & Cumulative Percent \\
\hline Valid & One credit card & 50 & 58.8 & 58.8 & 58.8 \\
\hline & Two credit cards & 13 & 15.3 & 15.3 & 74.1 \\
\hline & Three credit cards & 15 & 17.6 & 17.6 & 91.8 \\
\hline & Five credit cards & 6 & 7.1 & 7.1 & 98.8 \\
\hline & Seven credit cards & 1 & 1.2 & 1.2 & 100.0 \\
\hline & Total & 85 & 100.0 & 100.0 & \\
\hline
\end{tabular}

Table 1 shows that the most of the users, almost 59\% respondents possess single credit card. However, some users have more than six credit cards in their wallets. This may be due to the issuers' aggressive interest to supply with credit cards to potentially eligible customers with a view to promoting individual business.

Table 2. Monthly income of respondents

\begin{tabular}{|c|c|c|c|c|c|}
\hline \multicolumn{2}{|c|}{} & Frequency & Percent & Valid Percent & Cumulative Percent \\
\hline Valid & BDT.21000 to 30000 & 24 & 28.2 & 28.2 & 28.2 \\
\hline & BDT.31000 to 40000 & 21 & 24.7 & 24.7 & 52.9 \\
\hline & BDT.41000 to 50000 & 16 & 18.8 & 18.8 & 71.8 \\
\hline & BDT.51000 to 60000 & 8 & 9.4 & 9.4 & 81.2 \\
\hline & BDT.60000 and above & 16 & 18.8 & 18.8 & 100.0 \\
\hline
\end{tabular}

Table 2 shows the income level of participants in the survey. About $80 \%$ of the respondents have an income level between Tk. 21,000 and Tk. 60,000; and rest of 20\% has income above Tk. 60,000.

Table 3. Credit limit of the credit card users

\begin{tabular}{|c|c|c|c|c|c|}
\hline \multicolumn{2}{|c|}{} & Frequency & Percent & Valid Percent & Cumulative Percent \\
\hline Valid & Up to tk.1,00,000 & 15 & 17.6 & 17.6 & 17.6 \\
\hline & Up to tk.5,00,000 & 29 & 34.1 & 34.1 & 51.8 \\
\hline & Any other amount & 41 & 48.2 & 48.2 & 100.0 \\
\hline & Total & 85 & 100.0 & 100.0 & \\
\hline
\end{tabular}

Table 3 shows credit limits are mostly up to Tk. 5,00,000 (option 2), which is about 34\% of customers. But many customers (about 48\%) ticked the option of 'any other amount' which appeared to be both below option 1 of up to Tk. $1,00,000$ and option 2 .

Table 4. Outstanding on the credit card

\begin{tabular}{|c|c|c|c|c|c|}
\hline \multicolumn{2}{|c|}{} & Frequency & Percent & Valid Percent & Cumulative Percent \\
\hline Valid & BDT.1000 to 100000 & 23 & 27.1 & 27.1 & 27.1 \\
\hline & BDT.101000 to 200000 & 10 & 11.8 & 11.8 & 38.8 \\
\hline & BDT.201000 to 300000 & 9 & 10.6 & 10.6 & 49.4 \\
\hline & BDT.301000 to 400000 & 2 & 2.4 & 2.4 & 51.8 \\
\hline & BDT.401000 to 500000 & 1 & 1.2 & 1.2 & 52.9 \\
\hline & Any other amount & 40 & 47.1 & 47.1 & 100.0 \\
\hline
\end{tabular}

Table 4 reveals the outstanding balance in the credit card to be mostly between Tk. 1000 and Tk. 1,00,000 for $27 \%$ of the customers using credit cards. However, the option for 'any other amount' which was ticked by $47 \%$ of the customers, showed that many of the option 6 as was specified by the customers were within the option 1 of balance between Tk. 1000 and Tk. $1,00,000$. So, the combined percentage of option 1 and option 6 would be the highest of $74 \%$. Besides these, the outstanding balance between Tk. 1,00,000 and Tk. 5,00,000 in the credit cards is about $25 \%$ of the customers, which may reflect a bad sign that users may have ended up with difficulties either in repaying the balance or with the debt incurred through the excessive use of credit cards. 
Table 5. Time takes to pay out credit card balance

\begin{tabular}{|c|c|c|c|c|c|}
\hline \multicolumn{2}{|c|}{} & Frequency & Percent & Valid Percent & Cumulative Percent \\
\hline Valid & One-off payment of whole balance & 10 & 11.8 & 11.8 & 11.8 \\
\hline & Minimum payment every month & 40 & 47.1 & 47.1 & 58.8 \\
\hline & Other mode of payment & 35 & 41.2 & 41.2 & 100.0 \\
\hline & Total & 85 & 100.0 & 100.0 & \\
\hline
\end{tabular}

Table 5 shows the frequency analysis of time repayment that one-off payment of the full outstanding balance method was only used by $12 \%$ of the credit card users, whereas the minimum payment method was embarked on by $47 \%$, i.e. approximately by half of the customers, which may be a warning sign of strain in repayment and accumulation of debt. Again, the minimum plus occasional payment method was used by $41 \%$ of the users, which may appear to be good news, however, this again will depend on how much additional to minimum required amount is being paid. Paying off the outstanding balance is the most effective way of managing credit cards, because the more time one takes to repay it, the more interest one pays. However, it appears that there is a wide variation between mode of repayment i.e. between one-off payment and the minimum payment methods. We also observed in table 1 that the credit cards mostly used by the age group of 21 to 40 years, which is considerably higher than the other age groups.

Table 6. Interest rate charged on credit card

\begin{tabular}{|c|c|c|c|c|c|}
\hline \multicolumn{2}{|c|}{} & Frequency & Percent & Valid Percent & Cumulative Percent \\
\hline Valid & $30 \%$ & 80 & 94.1 & 94.1 & 94.1 \\
\hline & Any other rate & 5 & 5.9 & 5.9 & 100.0 \\
\hline & Total & 85 & 100.0 & 100.0 & \\
\hline
\end{tabular}

Table 6 shows the companies prevailing interest rate charged by the credit card issuers. In most instances, $94 \%$ of credit cards charge interest rate of $30 \%$. For the remaining $6 \%$, the charge varied from $18 \%$ to $24 \%$; and this was only charged by a few banks, namely City Bank Visa Card, depending on the individual customer profile and the range of spending or use of cards.

Table 7. User-friendly or complicated to use of credit card

\begin{tabular}{|c|c|c|c|c|c|}
\hline \multicolumn{2}{|c|}{} & Frequency & Percent & Valid Percent & Cumulative Percent \\
\hline Valid & Highly user-friendly & 11 & 12.9 & 12.9 & 12.9 \\
\hline & User-friendly & 49 & 57.6 & 57.6 & 70.6 \\
\hline & $\begin{array}{c}\text { Neither user-friendly nor } \\
\text { complicated }\end{array}$ & 23 & 27.1 & 27.1 & 97.6 \\
\hline & Complicated & 2 & 2.4 & 2.4 & 100.0 \\
\hline & Total & 85 & 100.0 & 100.0 & \\
\hline
\end{tabular}

Table 7 reflects how user-friendly the customers find the use of credit cards. About $58 \%$ of customers find it user-friendly with $13 \%$ finds it highly user-friendly. However, a good number of users, more than $27 \%$ found it neither user-friendly nor complicated with only less than 3\% found it complicated. If options 1, 2 and 3 are combined, it shows that more than $97 \%$ of customers did not find the use complicated, whereas only $2 \%$ found it complicated.

Table 8. The use of credit card cost-effective and satisfactory

\begin{tabular}{|c|c|c|c|c|c|}
\hline \multicolumn{2}{|c|}{} & Frequency & Percent & Valid Percent & Cumulative Percent \\
\hline Valid & Highly cost-effective and satisfactory & 1 & 1.2 & 1.2 & 1.2 \\
\hline & Moderately cost-effective and satisfactory & 6 & 7.1 & 7.1 & 8.2 \\
\hline & Cost-effective and satisfactory & 20 & 23.5 & 23.5 & 31.8 \\
\hline & Neither cost-effective nor satisfactory & 33 & 38.8 & 38.8 & 70.6 \\
\hline & Not at all cost-effective or satisfactory & 25 & 29.4 & 29.4 & 100.0 \\
\hline & Total & 85 & 100.0 & 100.0 & \\
\hline
\end{tabular}

Table 8 reveals how cost-effective and satisfactory were the use of credit cards. More than $29 \%$ of users found it 'not at all cost-effective or satisfactory' and about $39 \%$ fond it 'neither cost-effective nor satisfactory'. However, about one quarter of the users fond it to be cost-effective and satisfactory. This needs to be investigated further why $70 \%$ of customers still use the card though they found it 'neither cost-effective nor satisfactory.' It may be because they are encouraged by the card issuers or allured by their offers like 'buy now, pay later' at the time of need of credit card facilities and thereby spending more through immediate consumption Lury [22] without having any strategies of repayment. 
Table 9. Security of credit card

\begin{tabular}{|c|c|c|c|c|c|}
\hline \multicolumn{2}{|c|}{} & Frequency & Percent & Valid Percent & Cumulative Percent \\
\hline Valid & Highly secured & 15 & 17.6 & 17.6 & 17.6 \\
\hline & Fairly secured & 43 & 50.6 & 50.6 & 68.2 \\
\hline & Neither secured nor unsecured & 3 & 3.5 & 3.5 & 71.8 \\
\hline & Fairly unsecured & 21 & 24.7 & 24.7 & 96.5 \\
\hline & Highly unsecured & 3 & 3.5 & 3.5 & 100.0 \\
\hline & Total & 85 & 100.0 & 100.0 & \\
\hline
\end{tabular}

Table 9 shows that $18 \%$ users found the credit card use to be highly secured, nearly $51 \%$ found it fairly secured, whereas about $25 \%$ i.e. one quarter of users found it fairly unsecured with nearly $4 \%$ highly unsecured. Nearly $70 \%$ of the users found it the use to be secured, which is considerably higher than those who find it unsecured.

Table 10. Paying off balance and have debt now

\begin{tabular}{|c|c|c|c|c|c|}
\hline \multicolumn{2}{|l|}{} & Frequency & Percent & $\begin{array}{c}\text { Valid } \\
\text { Percent }\end{array}$ & $\begin{array}{c}\text { Cumulative } \\
\text { Percent }\end{array}$ \\
\hline Valid & Yes & 50 & 58.8 & 58.8 & 58.8 \\
\hline & No & 35 & 41.2 & 41.2 & 100.0 \\
\hline & Total & 85 & 100.0 & 100.0 & \\
\hline
\end{tabular}

Table 10 reveals if the credit card users find any difficulties in repaying the card loan. About $59 \%$ of the users find it difficult to keep repayments up-to-date and those have accumulated as debt now. However, $41 \%$ of the users stated that they did not find any difficulty paying off the balance.

Table 11. Affecting budget and finances

\begin{tabular}{|c|c|c|c|c|c|}
\hline \multicolumn{2}{|c|}{} & Frequency & Percent & $\begin{array}{c}\text { Valid } \\
\text { Percent }\end{array}$ & $\begin{array}{c}\text { Cumulative } \\
\text { Percent }\end{array}$ \\
\hline Valid & Yes & 51 & 60.0 & 60.0 & 60.0 \\
\hline & No & 34 & 40.0 & 40.0 & 100.0 \\
\hline & Total & 85 & 100.0 & 100.0 & \\
\hline
\end{tabular}

Table 11 depicts how the credit card debt affects personal finance and budget. $60 \%$ of users experienced financial difficulties coping with the credit card debt and $40 \%$ of the users were oaky with the use of credit card and repayments.

Table 12. Quality of service provided by the credit card issuers

\begin{tabular}{|c|c|c|c|c|c|}
\hline \multicolumn{2}{|c|}{} & frequency & Percent & $\begin{array}{c}\text { Valid } \\
\text { Percent }\end{array}$ & $\begin{array}{c}\text { Cumulative } \\
\text { Percent }\end{array}$ \\
\hline Valid & Excellent & 2 & 2.4 & 2.4 & 2.4 \\
\hline & Good & 28 & 32.9 & 32.9 & 35.3 \\
\hline & Average & 21 & 24.7 & 24.7 & 60.0 \\
\hline & Poor & 13 & 15.3 & 15.3 & 75.3 \\
\hline & Very poor & 21 & 24.7 & 24.7 & 100.0 \\
\hline & Total & 85 & 100.0 & 100.0 & \\
\hline
\end{tabular}

Table 12 shows the quality of service provided by the credit card issuers whilst their customers face financial difficulties with the credit card debt. The quality of service ranked by the users of credit cards as excellent by $2.4 \%$, as good by $33 \%$, average by $25 \%$, poor by $15 \%$ and very poor by $25 \%$.

\section{Test of Hypotheses}

\subsection{Hypothesis 1}

Ho: There is a significant effect of respondents' age on the duration of repaying the balance.

Ha: There is no significant effect of respondents' age on the duration of repaying the balance.

Table 13. ANOVA

\begin{tabular}{|c|c|c|c|c|c|}
\hline & $\begin{array}{c}\text { Sum of } \\
\text { Squares }\end{array}$ & df & $\begin{array}{c}\text { Mean } \\
\text { Square }\end{array}$ & F & Sig. \\
\hline $\begin{array}{c}\text { Between } \\
\text { Groups }\end{array}$ & 4.585 & 4 & 1.146 & 2.773 & .033 \\
\hline $\begin{array}{c}\text { Within } \\
\text { Groups }\end{array}$ & 33.062 & 80 & .413 & & \\
\hline Total & 37.647 & 84 & & & \\
\hline
\end{tabular}

Table 13 shows the main ANOVA result - to see if the group means are the same represented by the F-ratio for the combined between group effect. The final column labeled significance indicates how likely it is that an F-ratio of that size would have occurred by chance. In this case, the probability ratio is 0.033 . For a cut-off point of 0.05 for statistical significance, we could confidently say that there is a significant effect of respondent's age on the duration of repaying the balance.

\subsection{Hypothesis 2}

Ho: There is a significant effect of respondents' findings the card use uncompleted on difficulties in repayment and running into debt.

Ha: There is no significant effect of respondents' findings the card use uncompleted on difficulty ties in repayment and running into debt.

Table 14. ANOVA

\begin{tabular}{|c|c|c|c|c|c|}
\hline & $\begin{array}{c}\text { Sum of } \\
\text { Squares }\end{array}$ & df & $\begin{array}{c}\text { Mean } \\
\text { Square }\end{array}$ & F & Sig. \\
\hline $\begin{array}{c}\text { Between } \\
\text { Groups }\end{array}$ & 3.331 & 3 & 1.110 & $\begin{array}{c}5.21 \\
1\end{array}$ & .002 \\
\hline $\begin{array}{c}\text { Within } \\
\text { Groups }\end{array}$ & 17.257 & 81 & .213 & & \\
\hline Total & 20.588 & 84 & & & \\
\hline
\end{tabular}

Table 14 shows the main ANOVA result. The final column showing significance level indicates how likely it is that an F-ratio of 5.211 would have occurred by chance. In this case, the probability ratio is 0.002 . For a cut-off point of 
0.05 for statistical significance, we could confidently say that there is a significant effect of respondents finding the card use uncomplicated on difficulties in repayment and running into debt.

\subsection{Hypothesis 3}

Ho: The duration of repayment of credit card balance neither cost effective nor satisfactory.

Ha: The duration of repayment of credit card balance either cost effective or satisfactory.

Table 15. ANOVA

\begin{tabular}{|c|c|c|c|c|c|}
\hline & $\begin{array}{c}\text { Sum of } \\
\text { Squares }\end{array}$ & df & $\begin{array}{c}\text { Mean } \\
\text { Square }\end{array}$ & F & Sig. \\
\hline $\begin{array}{c}\text { Between } \\
\text { Groups }\end{array}$ & 7.001 & 4 & 1.750 & 4.569 & .002 \\
\hline $\begin{array}{c}\text { Within } \\
\text { Groups }\end{array}$ & 30.646 & 80 & .383 & & \\
\hline Total & 37.647 & 84 & & & \\
\hline
\end{tabular}

Table 15 shows that customers who found the card use 'neither cost-effective nor satisfactory' have statistically significant effect, with between group effect with F-statistic of 4.569 and significance level of 0.002 , on the duration of repayment of credit card balance.

\subsection{Hypothesis 4}

Ho: There is a significant difficulty in paying off the balance of debt.

Ha: There is no significant difficulty in paying off the balance of debt.

The question relating to hypothesis was: Do you find any difficulty in paying off the balance and do you have any debt now?

Table 16. On the basis of the responses of the 85 respondents' the following is designed:

\begin{tabular}{|c|c|c|}
\hline Scale of Responses & $\begin{array}{c}\text { Number of } \\
\text { Responses }\end{array}$ & Percentage \\
\hline Yes & 50 & $59 \%$ \\
\hline No & 35 & $41 \%$ \\
\hline $\begin{array}{c}\text { Total Collected Data } \\
(2014)\end{array}$ & 85 & $100 \%$ \\
\hline
\end{tabular}

Source: Filed Survey

Formulating the hypothesis: The researcher's formulated the null hypothesis (Ho), that the number of success sample:

$\mathrm{X}$ equal to $50: \mathrm{Ho}=50$

$\mathrm{X}$ is not equal to $50: \mathrm{Ho} \neq 50$

Formula of $\mathrm{Z}$ test is:

$$
\begin{aligned}
& \mathrm{Z}=\frac{\frac{X}{n}-p}{\sqrt{p}} \\
& =\frac{\frac{X}{n}-p}{\sqrt{\frac{p(1-p)}{n}}} \\
& =1.62
\end{aligned}
$$

Since calculated value of $\mathrm{Z}$ is 1.62 which is lower than $Z$-table value (i.e. \pm 1.64 ) at $5 \%$ level of significance. It falls inside the acceptance region. So, therefore, we must accept null hypothesis (Ho) and alternative hypothesis (Ha) must be rejected. Hence, it can be said that, there is a significant difficulty in paying off the balance of debt.

\subsection{Hypothesis 5}

Ho: There is a significant effect of difficulties in repayment and debt level on budgeting and personal finance of credit card users.

Ha: There is no significant effect of difficulties in repayment and debt level on budgeting and personal finance of credit card users.

Table 17. ANOVA

\begin{tabular}{|c|c|c|c|c|c|}
\hline & $\begin{array}{c}\text { Sum of } \\
\text { Squares }\end{array}$ & df & $\begin{array}{c}\text { Mean } \\
\text { Square }\end{array}$ & F & Sig. \\
\hline $\begin{array}{c}\text { Between } \\
\text { Groups }\end{array}$ & 3.280 & 4 & .820 & 3.832 & .007 \\
\hline Within Groups & 17.120 & 80 & .214 & & \\
\hline Total & 20.400 & 84 & & & \\
\hline
\end{tabular}

Table 17 - the ANOVA results shows the significance level indicating the probability ratio of 0.007 for an F-ratio of 3.832. For a cut-off point of 0.05 for statistical significance, we could confidently say that there is a statistically significant effect of difficulties in repayment and debt level on budgeting and personal finance of credit card users.

\section{Discussions of the Results}

This descriptive study was attempted to outline the extent of use of credit cards and its implications on over-indebtedness and difficulties in personal finance, and how the credit cards are viewed by the customers in general and how the card issuers provide information and support to the card users at the time of marketing and managing the industry. The findings of the survey reveal that the card use varies significantly with the age of the users-the young age groups use the cards more frequently as they found it to be user friendly and secured; the more they use the cards, the more interest they pay on their borrowing, because nearly half of the users attempt to pay only the minimum required amount-thereby attracting more and more interest on the remaining balance; and most strikingly, majority of the users are found to be in difficulties in keeping up repayments and were affected by debt in many ways, e.g. consumption and saving. The survey further reveals that the quality of service provided by the card issuers at the time when the customers face difficulties with repayments and debt is quantitatively meager and not up to the mark.

The response rate in our survey was $93 \%$, which is more than the prescribed response rate for survey method to overcome non-response bias (Moser \& Kalton, 1985). There is a consensus for questionnaire survey that the response rate 
of $60 \%$ or more is required to make it adequately representative and to make the result of the survey credible and acceptable(Bowling, 2002). A review of published GP studies also showed a mean response rate of $61 \%$ (Barclay, Todd, Finlay, Grande, \& Wyatt, 2002). The increased response to questionnaires in our survey can be attributed to personalized letters to the Bank Managers (Appendix 2) for providing us with list of credit card users obtaining prior consent of them, contacting participants before actual interview or filling in questionnaires, introductory letters to the respondents, ensuring the questionnaire was as brief as possible with clear instructions for completion, using both physical and telephone methods for interview as well as through email, reminder or follow-up contacts by phone call before the actual interview, and providing non-responders with further reminder call of the interview as well as an assurance of the feedback of survey result. All these strategies have been shown to be effective in increasing response rate in survey research in a systematic review by (Edwards, et al., 2002) and in research paper by (Walonick, 1993). Response rate is claimed to be the single most important indicator for the results to be credible and reliable as low response rate may be devastating to the confidence of the results. Critics though argue that increased response rate does not always increase the precision of survey results cited in (Walonick, 1993) as there are other factors e.g. the overall design of the study, content validity of the questionnaire, the target populations data analysis and reporting, etc. also play important roles.

\section{Limitations of the Study}

(1) Observational study does not always provide sufficiently robust evidence to recommend changes in practice;

(2) There could be a criticism that we did not define meant by cost-effectiveness in the questionnaire, however, we thought that this is a very practicable measure;

(3) We did not have a good response on questions on cost-effectiveness, which may be a fault on questionnaire design;

(4) We did not define the terms of ranking e.g. excellent or very poor, so the answers may have response bias;

(5) There may be a response bias as we only targeted users of credit cards, and not the providers;

(6) We do not know the quality of service offered by the issuers/banks unless we interview the service providers.

\section{Findings of the Study}

(1) People at younger age groups are often adventurous. Jaing [30] has found that credit card use varied considerably with age of the consumers. It is often felt when one pays cash that the money is leaving you. This may not be true with credit cards as flipping a credit card up on a counter registers nothing emotionally about money leaving you other than you are buying something which could have been unaffordable or you wouldn't have attempted to buy for cash. A study of credit card use at McDonald's found that people spent $47 \%$ more when using credit card instead of cash payment.

(2) Number of credit cards in the wallet - reflects potential financial eligibility of a customer. Users with more than one card may not use their cards very often as shown by the survey result that $59 \%$ of the card users possess a single card. Paradoxically less affluent customers are more prone to use credit cards than multiple card holders, which have been established by the answers to the income question showing that monthly income level between Tk. 21,000 and Tk. 60,000 are the most card users than those having an income level above Tk. 60,000 (Willamson, 2010). The survey also revealed that those having income level above Tk. 60,000 pays their outstanding balance with a one-off payment within the deadline before any interest is accrued, whereas those having lower income than Tk. 60,000 end up paying by the minimum amount $(47 \%)$ and mixed payment method (41\%), both of which attract very high interest during the lifetime of the balance. This paves the way of never-ending infectious habit of making the indiscreet use of credit card that results in overwhelming credit card debt, which very much correlates with survey result.

(3) The dramatic increase in the credit card use in our country over the last few years may be due to the fact that the customers find it very user-friendly and secured. Besides these, the credit card companies are putting their highest efforts to make the facilities easily and highly available working with the retailers and attracting the customers with the philosophy of 'buy no, pay later'. It can be argued that the liberalization of the financial services industry is linked to the increased availability of debt products and it helps to provide the money that fuels immediate consumption.

(4) Though there are various factors playing their roles in increasing the trend in using the plastic credit cards, it has been revealed by the survey that the majority of the customers did neither find the use 'cost-effective' nor 'satisfactory'. It clearly raises a signal to further research and to look into the facts why people are using credit card borrowing more and more, even when they find them neither cost-effective nor satisfactory. This may again be argued here that this contradictory behavior of the consumers results from the excessive liberalization of financial services and aggressive encouragement 
of uptake of debt facilities by the banks and other financial institutions, which may be attributed to a positive link between consumption behavior and credit growth Bacchetta and Gerlach [32].

(5) The survey very clearly depicts that majority of the participants $(60 \%)$ find it difficult to keep up repayments and how the accumulating debt is seriously affecting the budgeting and personal finance leading to erratic consumption and decreased saving and or no saving at all. Different strategies should be developed and investigations initiated at governmental levels to legislate the credit card industry, which might be targeted to modify the behavior of the industry and that of the consumers as well (Dunn \& Kim, 1999). The survey result showed striking evidence that the majority of participants (60\%) using credit cards ended up with debt and resultantly with erratic consumption behavior and serious interference with saving behavior, which is consistent with the standard life-cycle model of saving behavior. It holds that, over their lifetimes, consumers strive to achieve a target ratio of net worth to income that will allow them to maintain their desired consumption patterns through retirement (Skinner, 2007).

(6) Survey result is very much consistent with the studies cited above in that $60 \%$ of survey participants indicated that they either found difficulties which arose out of their increased consumption behavior ran into debt with financial crisis and thereby they were bound to modify their saving. In some instances, they stopped their usual saving practices, e.g. saving stopped or withheld or even cashed out to defray other essential expenses, children's saving plans, children's insurance policies stopped or cashed out, pensions policies or plans stopped or even cashed out, fixed deposits instruments or plans sold out etc. These reflects how gloomy the picture is because of indiscriminate use of credit cards borrowing and how badly the budgeting and personal finance have been affected through an increase in the financial obligation ratio (Johnson, 2005). Personal Finance is claimed to be $80 \%$ dependent on behavior. One needs to cut out habits that make one spend more (Dynan, 1993).

(7) The survey participants found the quality of service as good $(33 \%)$ with less than a quarter finding it average, however, more than $40 \%$ of them found it either poor or very poor, which may be quite alarming as a significant percentage of card users are not getting the right service, let alone a quality service from the card issuers. It reveals that only about $33 \%$ of customers ranked the service as good with only $2 \%$ ranking it as excellent, whereas the rest of $65 \%$ ranked it average, poor and very poor, which is consistent with findings that about $60 \%$ of card users found difficulties in repayment and crises with debt, budgeting and personal finance. It appears that those people, who end up in financial difficulties and debt, are not getting appropriate information, guidance and support with their difficulties and debt management or any other help which could have changed or modified their situations. This also reflects that banks or other card issuers are not considering the implications of aggressive encouragement of uptake of credit facilities. Not only that, in addition the survey reveals, from the answers of questions 11 and 12, that they are not providing enough information so that customers can make informed choices and decisions.

(8) The offers made by the banks are deceitfully alluring to the customers' e.g. complimentary meal, complimentary air tickets, and many others when they market and promote their products, however, the charges made by the banks are deceitfully high and multiple, like late fee or other hidden charges. No banks offer benefits of low interest rate, which is one of the most intriguing elements of credit card debt. Despite all these debt encouraging strategies, it's time now for the banks in our country to develop debt counseling services with a view to offering support to a wide group of customers facing financial difficulties and debt, which amounts to about $60 \%$ of credit card users according to the survey. Considering the huge number of customers $(60 \%)$ facing financial difficulties and debt according to the survey, there should be a priority development of guidelines and legislative framework to offer formal help to those in need. It is further considered that an investigation should be initiated to find out why such a substantial number of credit card users are ending up with such financial difficulties and, accordingly, develop and modify services to closely monitor the behaviors of both providers and consumers with a view to stabilizing personal fiancé in this era of rapid credit growth.

\section{Recommendations of the Study}

(1) There is an overwhelming need for further investigation into guidelines development and implementation, availability and compliance with those guidelines, with pragmatic approach involving both providers and users of credit cards, which will inform future direction.

(2) A uniform strategy be developed to identify the burning issues around credit card use, backed by adequate infrastructure, resources trained workforce, to smoothen the process of effective implementation of provision of information and to improve access of the users with a view to ensuring responsible lending and borrowing; and to see responsible lending principles developed and respected by all concerned 
to protect the most vulnerable.

(3) Regular reports on compliance to implement process and provision of structured information by the Banks/Issuers for the users to Bangladesh Bank and any other Governance of the Banks as a way of continuous monitoring; also consumers groups should be entrusted to monitor the availability of appropriate information for the users and pinpoint the gaps in service provision.

(4) Compliance with the guidelines, structured information provision and organized support in dealing with debt and difficulties in personal finances should be on the performance indicators of the banks or issuers to be available for inspection by Bangladesh Bank Annual Report 2009-2010, Bangladesh Bank [37].

(5) A dedicated section of the banks to act as a single point of information for new and prospective credit card users, should liaise with people who are continuing to use the credit cards to warn of them of possible implications, to encourage people to finish off paying the balance at one go or the soonest possible with a budgeting approach as paying the minimum payment is convenient but accrues very high interest; to offer debt settlement and counseling service for those who are in potential financial difficulties; offering new measures to provide breathing space for those who want to repay their debts.

(6) Credit card guidelines development would be welcomed by all as an opportunity to raise the standards and consistency of services offered by banks and users to better understand them. User involvement should be ensured at all levels of guidelines development and implementation process to make it more participatory and effective.

(7) User's experience of credit card use should be feedback with a view to service improvement and there should be Alternative Dispute Resolution Scheme established with a view to dealing with consumer credit complaints.

(8) Regular national audits and feedback on compliance with guidelines and implementation programme by the banks or issuers should be conducted with a view to getting evidence into practice.

(9) Planning of consumer education programmes by the banks, e.g. launch of 'Debt Test' an online self-assessment tool for assessing financial capacity, particularly among young people who are seen to use the credit card facilities more, so that they can take control of their finances and participate defectively in the credit market.

(10) And above all, to encourage saving behavior and culture, which have been seen to be seriously affected in our survey, to avoid over-indebtedness.

It would be a far cry in this modern era of living on credit to aspire for the "brilliant frugal living" which people had experienced before the debt addiction had taken hold of our lives (Sandberg, 2012). However, every effort should be made so that people are sufficiently empowered to use the credit card facilities to their benefit rather than the credit growth taking hold of their lives and to be able behave responsibly in respect of consumption and saving in this era of expanding credit growth.

\section{Conclusions}

There are very studies in the country, which investigated the level of credit cards and the resultant debt and difficulties in finance. Nonetheless, few studies in the past indicated that the advances made by the banks were high, even though the eligibility criteria for credit cards were difficult. However, improved provision of information on the use of credit cards must be ensured by banks and other issuers of credit cards, minimizing the inter-bank variation in this provision to become responsible lenders with a view to helping customers to make informed choices and decisions about using the credit card facilities in a responsible and efficient way. For the increased availability and accessibility of information to an expected and acceptable level, regarding the pros and cons of use of credit cards, which has, to some extent convincing evidence to benefit and cost-effectiveness, there has to be widespread systematic, coordinated and effective guidelines development and implementation of those with a view to helping potential customers. This study has showed that the uptake of use of credit cards is indiscriminate and promiscuous with minimal degree of rational thinking and, thereby, the people are gradually drowning themselves in the credit card debt and rendering them into a state of chaos and difficulty with poorly managed personal finances.

\section{REFERENCES}

[1] Michelle Norris, Economic decline in a culture of credit, July 2008.

[2] A.N.M. Farukh. Analysis on Credit Card Market Bangladesh, www.slideshare.net, 2009.

[3] R. Manning. Credit Card Nation: The Consequence of America's Addiction to Credit. United States of America, Basic Books, 2001.

[4] A. Furnham, M. Argyle. The Psychology of Money, London, Rout ledge, 1998.

[5] Q. May, M. Tudela, G. Young, G. British Household Indebtedness and Financial Stress: A Household-level D, Bank of England Quarterly Bulletin, Winter, pp. 414-428, 2004.

[6] S. Huq. Debit Card/Credit Card-Service Annoyance or Service Utility. Bank Info BD, May 2011.

[7] Scheduled Bank Statistics: Bangladesh Bank, Quarterly: October to December, 2011. 
[8] A.N.M. Farukh. Analysis on Credit Card Market Bangladesh, www.slideshare.net, 2009.

[9] A.N.M. Farukh. Analysis on Credit Card Market Bangladesh, www.slideshare.net, 2009.

[10] P. Andrew. www.indexcreditcards.com, 2011.

[11] K. Mathews. Americans Still Under the Burden of Credit Card Debt, Patriot Statesman, USA, 2012.

[12] S. Jaing. Credit Card and Payoff: A Lifecycle Analysis, Ohio State University, Mimeo, 2006.

[13] S. D. Williamson. Macroeconomics-“A Two-Period Model: The Consumption Savings Decision and Credit Markets", Canada, Pearson Canada, 2010.

[14] L. Farinha. Households Debt Burden: An Analysis Based on Microeconomic Data, 2004.

[15] C. Lury. Personal Finance: Debt and Borrowing in its Wider Context, 2004.

[16] P. Bacchetta, S. Gerlach. Consumption and Credit Constraints: International Evidence, Journal of Monetary Economics, Issue 40, pp.207-238, 1997.

[17] P. Bacchetta, S. Gerlach. Consumption and Credit Constraints: International Evidence, Journal of Monetary Economics, Issue 40, pp.207-238, 1997.

[18] D. M. Maki. The Growth of Consumer Credit and the Household Debt Service Burden, Board of Governors of the Federal Reserve System, Finance and Economics Discussion Paper: 2000/12.

[19] J. Golmant, T. Ulrich. Aging and Bankruptcy. The Baby Boomers Meet Up at the Bankruptcy Court, American Bankruptcy Institute Journal, Issue No. 26, 2007.

[20] S.P. Calem, M. J. Loretta. Consumer Behavior and Stickiness of Credit Card Interest Rates, American Economic Review, Vol. 85, Issue No. 5, pp. 1327-1336, 1995.

[21] J. Soong. The Debt-stress Connection, http://www.webmd.com, 2008.

[22] C. Lury. Personal Finance: Debt and Borrowing in its Wider Context, 2004.

[23] A.C. Moser, G. Kalton. (1971). Survey Methods in Social Investigation, London: Heinemann, 1971.

[24] A. Bowling. Research Methods in Health: Investigating Health and Health Services, Buckingham, Open University
Press, 1997.

[25] S. Barclay, C. Todd, I. Finlay. Not Another Questionnaire! Maximizing the Response Rate, Predicting Non-response and Assessing Non-response Bias in Postal Questionnaire Studies of GPs, Family Practice, Issue No. 19, pp. 105-111, 2002.

[26] P. Edwards, I. Roberts, M. Clarke. Increasing Response Rates to Postal Questionnaires: Systematic Review, British Medical Journal, 324:1183, 2002.

[27] D. Walonick. Stat Pack Gold IV: Marketing Research and Survey Edition, Minneapolis, www.statpac.com/research-papers/research-process.htm, 1993.

[28] D. Walonick. Stat Pack Gold IV: Marketing Research and Survey Edition, Minneapolis, www.statpac.com/research-pa pers/research-process.htm, 1993

[29] D. Walonick. Stat Pack Gold IV: Marketing Research and Survey Edition, Minneapolis, www.statpac.com/research-papers/research-process.htm, 1993.

[30] S. Jaing. Credit Card and Payoff: A Lifecycle Analysis, Ohio State University, Mimeo, 2006.

[31] S. D. Williamson. Macroeconomics-“A Two-Period Model: The Consumption Savings Decision and Credit Markets", Canada, Pearson Canada, 2010.

[32] P. Bacchetta, S. Gerlach. Consumption and Credit Constraints: International Evidence, Journal of Monetary Economics, Issue 40, pp.207-238, 1997.

[33] L. F. Dunn, Tae Hyung Kim. An Empirical Investigation of Credit Card Default, Working Paper\# 99-15, Ohio State University, October, 1999.

[34] J. Skinner. Are You Sure You're Saving Enough Retirement?, Journal of Economic Perspectives, Vol. 21, Issue No. 3, pp. 59-80, 2007.

[35] W. J. Kathleen, Recent Development in the Credit Card Market and the financial obligations Ratio, Federal Reserve Bulletin, August, 2005, pp.473-486, 2005.

[36] E. K. Dynan. How Prudent are Consumers?, Journal of Political Economy, Issue No. 101, pp. 1104-1113,1993.

[37] Annual Report 2009-2010, Bangladesh Bank.

[38] E. Sandberg. 'Mad Men' Money: Credit in the smoking era', www.creditcards.com, 2012. 